TITLE:

\title{
Chemical characterization of various parts of nipa palm (Nypa fruticans)
}

$\operatorname{AUTHOR}(\mathrm{S})$ :

Tamunaidu, Pramila; Saka, Shiro

\section{CITATION:}

Tamunaidu, Pramila ...[et al]. Chemical characterization of various parts of nipa palm (Nypa fruticans). Industrial Crops and Products 2011, 34(3): 1423-1428

\section{ISSUE DATE:}

2011-11

URL:

http://hdl.handle.net/2433/151882

\section{RIGHT:}

(C) 2011 Elsevier B.V.; This is not the published version. Please cite only the published version.; この論文は出版社版でありません。引用の際に は出版社版をご確認ご利用ください。 


\section{Chemical characterization of various parts of nipa palm (Nypa fruticans)}

Pramila Tamunaidu and Shiro Saka*

Department of Socio-Environmental Energy Science, Graduate School of Energy Science,

Kyoto University, Yoshida-honmachi, Sakyo-ku 606-8501, Kyoto, Japan

${ }^{*}$ Corresponding author:

Shiro Saka

Department of Socio-Environmental Energy Science,

Graduate School of Energy Science, Kyoto University,

Yoshida-honmachi, Sakyo-ku 606-8501, Kyoto, Japan

Tel/Fax: +81(0)75 7534738

Email address: saka@energy.kyoto-u.ac.jp 


\section{Abstract}

The current study was initiated to characterize various parts of nipa palm (Nypa fruticans) to establish whole utilization of this biomass as potential raw material for fuels and chemicals. Nipa consisting of frond, shell, husk and leaf was chemically characterized for cellulose, hemicellulose, lignin, starch, protein, extractives and inorganic constituents for its each part. The total chemical composition showed that the cellulose and hemicellulose contents were in the range of 28.9 to $45.6 \mathrm{wt} \%$ and 21.8 to $26.4 \mathrm{wt} \%$, respectively. The hemicellulose was rich with glucuronoxylan. The lignin content was 19.4 to $33.8 \mathrm{wt} \%$ with the highest lignin content found in leaf. The alkaline nitrobenzene oxidation products showed that nipa palm lignin mainly consists of guaiacyl and syringyl propane units with a small amount of p-hydroxyphenylpropane unit. Besides the main chemical components, starch, protein and extractives were also present in a significant amount from 2 to 8 wt\%. Additionally, the ash content as an inorganic constituent was high from 5.1 to $11.7 \mathrm{wt} \%$, consisting of major inorganic elements of $\mathrm{Na}, \mathrm{K}$ and $\mathrm{Cl}$ along with minor inorganic elements of $\mathrm{Mg}, \mathrm{Ca}, \mathrm{Si}, \mathrm{P}, \mathrm{S}$ and Al. Overall, each part of the nipa palm has its individual superior characteristics and could be exploited as lignocellulosic resources for fuels and chemicals.

Keywords: Nipa palm; Frond; Shell; Husk; Leaf; Chemical composition 


\section{Introduction}

Nipa (Nypa fruticans) is a monoecious palm with special characteristics. Contrast to usual palms like coconut (Cocos nucifera) and oil palm (Elaeis guineensis), it thrives in river estuaries and brackish water environment in which salt and fresh water mingle. Nipa differs from most palms in the lack of an upright stem, trunkless and develops its inflorescence at a height of about $1 \mathrm{~m}$ (Uhl, 1972). Nipa palms abundantly grow in Southeast Asia, northward to Philippines, Ryukyu Islands and southward to north Queensland. The largest natural nipa stands are found in Indonesia (700 000 ha), Papua New Guinea (500 000 ha) and Philippines (8 000 ha) (WAC, 2008). Nipa palms can also be found in Nigeria as it was introduced in 1906 to curb coastal erosion.

The widespread occurrence of nipa palms made rural communities to grow these palms in agriculture fields for limited use; e.g. sap from inflorescence stalk is used to make toddy, vinegar or boiled down to sugar and the fruits are used as local dessert or made into alcoholic beverage (Hamilton \& Murphy, 1988). Conversely, nipa palm leaves are a major source of thatching material, which is extensively used, by the poorer section of rural population in southwest Bangladesh (Rahman, 2000) but most parts of the nipa palm are left to decompose at its habitat.

It is believed that traditional forest users collect an average of 60000 metric tons per year of fronds throughout the Sundarban Reserve Forest (Jahan et al., 2006). Therefore, 
large amounts of biomass are produced in this particular environment and its characterization will create new unexploited raw materials for fuels and chemicals. Furthermore, Food and Agricultural Organization of the United Nations (FAO) described nipa palm as a non-threatened and underutilized palm in South Asia (FAO, 1998). Nipa palm is also regarded as an invading palm and having adverse economical impact on waterways and marine lives in Nigeria (Udofia and Udo, 2005) and therefore the government is willing to remove and destroy this large palm community.

This is due to limited understanding and less research on the total chemical characterization and mass commercial utilization of the nipa palm. Among few most recent evaluations; nipa fronds were used as composites for medium-density fiberboards (Kruse and Frühwald, 2001), pulping materials (Jahan et al., 2006) and even as heavy metal adsorbents (Wankasi et al., 2005). However, the outcome is still not well received and local communities may be looking for other lucrative alternatives since nipa palm is available in all seasons and frequency of harvest does not affect the growth of the palm. Parts of nipa palm are not bulk in density like oil palm and removal of these parts does not lead to depletion of organic matter or nutrients as nipa palm grows on rich natural nutrients provided by the river estuary or sea (Robertson et al., 1992).

Therefore, the current study was initiated to characterize various parts of nipa palm to evaluate its potential as a lignocellulosic material for further conversion to compounds useful 
for fuels and chemicals. Nipa frond, leaf, husk and shell were, therefore, subjected to standardize characterization such as chemical and elemental aspects to establish effective utilization of the whole nipa palm. 


\section{Materials and methods}

\subsection{Collection and pre-treatment}

The nipa palm (Nypa fruticans) used in this study was collected from Balobo Village, Infanta,

Philippines. The palms are maintained as a plantation next to a river estuary and believed to be from 20 to 50 years of age. The nipa palm parts characterized as shown in Fig. 1, consists of frond, leaves and fruit in which the fibrous husk and shell are separated. Before the analyses, these parts were rinsed in water to remove soil and mud. Then the parts were further air-dried to remove excessive water and moisture. The parts were milled through a screen with $0.5 \mathrm{~mm}$ diameter in a Wiley Mill 1029-C (Yoshida Seikakusho Co., Ltd.) and particles between 0.15 to $0.5 \mathrm{~mm}$ were used for chemical analyses. They were further oven-dried at $45^{\circ} \mathrm{C}$ for $2 \mathrm{~h}$ and kept in desiccator till their prior use.

\subsection{Determination of chemicals and elements in nipa palm}

Small amounts of samples were further dried at $105^{\circ} \mathrm{C}$ to achieve oven-dried weights to determine ash contents of non-extracted samples by incineration at $600^{\circ} \mathrm{C}$ for $2 \mathrm{~h}$. The ashes were qualitatively determined by JEOL JSM-5800 scanning electron microscope coupled with energy-dispersive X-ray (SEM-EDX) instrument at an accelerating voltage of $20 \mathrm{kV}$. Quantification of inorganic elements was done with Shimadzu AA-6300 atomic absorption spectroscopy (AAS) with a highly sensitive graphite furnace atomizer and Agilent G1600A capillary electrophoresis (CE) system. 
For other analyses, extractives were firstly removed from the oven-dried samples by extraction with acetone for $24 \mathrm{~h}$. The weight loss from this step was defined as acetone extractives. For these extractive-free samples, the analytical methods used to quantify the cellulose, hemicellulose and lignin compositions are according to Rabemanolontsoa et al. (2010). Since ash generally remains attached to the solid portions, ash correction by incineration at $600^{\circ} \mathrm{C}$ for $2 \mathrm{~h}$ was done on all holocellulose and lignin products to prevent overestimation of the total yield. Therefore, all yields of chemical fractions are reported to be ash-free.

Additionally, alkaline nitrobenzene oxidation analysis was carried out by following small modifications to standard methods as described by Chen (1992) and Katahira and Nakatsubo (2001). The products were mixed with trimethylsilylation (TMS) reagent [N,O-bis(trimethylsilyl)trifluoroacetamide (BSTFA): pyridine $(10: 1, \mathrm{v} / \mathrm{v})]$ and analyzed by gas chromatography with veratraldehyde as an internal standard. The alkaline nitrobenzene oxidation was done on the extractive-free nipa palm samples rather than isolated lignin because oxidations on isolated lignin gave poor results.

Liquid portion of neutral sugars and uronic acids from hemicellulose as well as alkaline nitrobenzene oxidation product analyses were carried out by Hitachi G-7000M and M-9000 gas chromatograph mass spectrometer (GC-MS) equipped with $30 \mathrm{~m} \times 0.25 \mathrm{~mm}$ i.d., $0.25 \mu \mathrm{m}$ CP-Sil 8 CB-Low Bleed/MS capillary column. Helium was used as carrier gas. The 
GC-MS settings for neutral sugars and uronic acids were according to Sundberg et al. (1996) and alkaline nitrobenzene oxidation products according to Ehara et al. (2005). Acid-soluble lignin was analyzed using ultraviolet (UV) light at a wavelength of $205 \mathrm{~nm}$ on a Shimadzu UV-Vis spectrophotometer 2400.

Additional methods for starch and protein determinations from extractive-free samples were made with starch content measured by colorimetric method (Humphreys and Kelley, 1961) and protein by using SuperKjel 1400 (ACTAC, Tokyo) coupled with an auto-titration unit through Kjeldahl method (AOAC Official Method, 2001) with a nitrogen factor of 6.25 . 


\section{Results and Discussion}

3.1 Chemical compositionTable 1 shows the obtained chemical composition of vari ous parts of nipa palm. The cellulose content as determined by a-cellulose was in the range of 28.9 wt $\%$ for leaf to 45.6 wt $\%$ for shell. For frond, $\alpha$-cellulose and hemicellulose content were 35.1 and $26.4 \mathrm{wt} \%$, respectively. This range was similar to our previous study on nipa frond from Thailand, whereby a-cellulose and hemicellulose obtained were 32.5 and 22.1 wt\%, respectively (Phaiboonsilpa et al., 2011). Similarly, Jahan et al. (2006) analyzed nipa frond from Bangladesh as potential pulping material, resulting in $36.3 \mathrm{wt} \%$ of $\alpha$-cellulose and $24.9 \mathrm{wt} \%$ of hemicellulose. Therefore, it is likely that nipa fronds from various habitats and region almost have the same chemical characteristics and are rich lignocellulosic material. Although collectively the holocellulose content of fronds are around $60 \mathrm{wt} \%$, it is still low compared to woods. However, its availability and abundance can be a valid basis for exploitation as raw materials for fuels and chemicals.

In nipa palm, the lignin content consisting of Klason lignin and acid-soluble lignin (ASL) was the highest in leaf with $33.8 \mathrm{wt} \%$ followed by husk with $28.8 \mathrm{wt} \%, 19.7 \mathrm{wt} \%$ in frond and 19.4 wt\% in shell. The lignin content was comparatively high in leaf probably due to the inclusion of its hard primary vein. The spectral analyses by UV spectroscopy showed that 1.5 to $2.1 \mathrm{wt} \%$ of the total lignin were ASL. The ASL contents of nipa palm 
were similar to hardwoods as reported by Yasuda et al. (2001). Musha and Goring (1974) suggested that high ASL content is from the high reactivity of syringyl nucleus to sulfuric acid and occurs in syringyl lignin rich biomass. To further clarify this, we performed alkaline nitrobenzene oxidation and detailed results are described later.

Additionally, starch and protein contents were also recorded. The starch and protein contents were low compared to other chemical compositions. Leaf samples recorded the highest starch and protein contents of 2.8 and $3.0 \mathrm{wt} \%$, respectively, whereas in shell, only 0.8 wt\% of protein was observed with no starch fraction at all. However relatively, protein was observed in all parts of nipa palm from 0.8 up to 3.0 wt\%. Even though the starch and protein fractions are usually low, water-soluble and easily removed, their yields are essential for total characterization of the whole biomass as shown in this study for which many researchers still tend to ignore.

Addition to the analyses mentioned above, extractives content with acetone extraction was also recorded. Even though extractives are not used in a great extent commercially, they are known to influence properties of the biomass and performance of biomass products. As measured, the extractives content was relatively low in nipa palm from 0.8 to $2.3 \mathrm{wt} \%$, as shown in Table 1.

Another minor chemical fraction is ash derived from inorganic constituents, which 
represents the non-biodegradable component present in the biomass. Nipa palm substantially contains higher ash content than most lignocellulosic materials such as sugarcane bagasse, wood or even biomass of other palms. The ash content of nipa frond was the highest at 11.7 wt\% followed by shell, husk and leaf at $8.2,8.1$ and 5.1 wt\%, respectively. Further explanation on ash and its inorganic constituents are given later.

As a whole, the chemical composition of all cell wall components was independently measured but summative total was in the range of 97.0 to $99.5 \mathrm{wt} \%$. Thus, the quantitative determinations for all chemical constituents used in this study are valid.

\subsection{Neutral sugars and uronic acid}

A detailed hemicellulose fraction of neutral sugars and uronic acid contents for various parts of nipa palm is shown in Table 2. Hemicellulose (1) are calculated values from the difference between holocellulose and a-cellulose contents. For hemicellulose (2), however, it was calculated from the actual values of neutral sugars and uronic acid as analyzed by acid methanolysis and quantified by GC-MS. As a result, the hemicellulose contents determined by these two independent methods are very comparable to each other, as in Table 2.

Based on these results, the hemicellulose content is the highest in frond at 25.7 
wt\% and lowest in husk at $21 \mathrm{wt} \%$. The main neutral sugars present were xylose, glucose, arabinose and galactose, while mannose and rhamnose contents were the lowest in all parts with only $0.3-1.0 \mathrm{wt} \%$ and $0.1-0.2 \mathrm{wt} \%$, respectively. It is apparent that the obtained results are similar among various parts of oil palm as reported by Shibata et al. (2008) and coconut fibers by van Dam et al. (2006), which are two other species in the Arecaceae family. These results were also comparable to the Poaceae family which contains the largest biomass used for bioethanol production like sugarcane, corn and wheat (Carpita and Gibeaut, 1993).

The major non-cellulosic polysaccharide in nipa palm contains xylose and uronic acid in the weight ratio of $4.4: 1$ in frond up to $11.3: 1$ in leaf. Therefore, nipa palm is believed to be one of the monocotyledons with glucuronoarabinoxylan as its major non-cellulosic polysaccharide. Reports by Jarvis (1994) on leaf cell walls of the oil palm were consistent with this present finding.

The hexose $\left(\mathrm{C}_{6}\right)$ and pentose $\left(\mathrm{C}_{5}\right)$ contents from hemicellulose in various parts of nipa palm are summarized in Table 3 . The $C_{6}$ content was in the range of 21.0 to 24.9 wt\% and $\mathrm{C}_{5}$ from 66.1 to 71.8 wt\% of the total hemicellulose with the remaining being uronic acid. 


\subsection{Phenylpropane units of lignin}

Quantitative determination of lignin was done to provide molar ratios of guaiacyl propane (G), syringyl propane (S) and p-hydroxyphenylpropane (P) units present in nipa palm. Table 4 shows the obtained molar ratio of $S$ and $P$ units as alkaline nitrobenzene oxidation products to $\mathrm{G}$ unit in lignin of various parts of nipa palm. The results show that nipa palm lignin is a p-hydroxyphenyl- guaiacyl- syringyl propane (P-G-S) type lignin and contains all these three units in a significant amount.

$\mathrm{S}$ unit appeared as the major degradation product, whereas $\mathrm{P}$ was the minor with a molar ratio of 0.1 to 0.2 . The ratio of $S$ to $G$ unit is from 1.0 to 4.9 . The large occurrence of $S$ unit compared to $G$ unit suggests that nipa palm lignin is similar to hardwood lignin. However, Creighton and Hibbert (1944) suggested that the presence of $P$ unit might be the distinguishing characteristics of monocotyledons. However, later research on other palms showed that $\mathrm{P}$ is detected in either small quantities or not detected at all and would, therefore, not be the distinguishing factor (Suzuki et al., 1998; Sun et al., 1999; Shibata et al., 2008). The minor presence of $P$ unit in nipa palm lignin indicated that the nipa palm would be similar to grass or straw lignin rather than hardwood. For example, monomeric compositions of corn stalk lignin are reported to be similar with respective molar ratio proportions of $0.1,1$ and 1.7 for $\mathrm{P}, \mathrm{G}$ and $\mathrm{S}$ units in lignin (Lapierre, 1993). 


\subsection{Inorganic elements}

Fig. 2 shows the EDX spectra of ashes obtained in incineration at $600{ }^{\circ} \mathrm{C}$ from various parts of nipa palm. The inorganic elements detected are $\mathrm{Na}, \mathrm{K}, \mathrm{Mg}, \mathrm{P}, \mathrm{S}, \mathrm{Ca}, \mathrm{Cl}$ and $\mathrm{Si}$. Similar elements were also noticed in our previous research on nipa frond from Thailand (Phaiboonsilpa et al., 2011). Additionally, a small amount of $\mathrm{Al}$ was detected in all samples except for frond. The observation was comparable to Tono et. al (2007) on traces of Al element in shell and husk of oil palm. Adversely, a study in Nigeria on husks of nipa palm showed P, Mg and Fe as its major elements and $\mathrm{Zn}, \mathrm{Na}, \mathrm{Ca}$ and $\mathrm{Cu}$ were detected as its minor elements (Osabor et. al, 2008). This is due to the increasing industrialization in Nigeria which has led to the presence of heavy metals in this environment. However, it can be concluded that nipa palm absorbs the rich source of inorganic elements readily available from its habitat, from salts like $\mathrm{NaCl}$ or $\mathrm{KCl}$ which naturally exist in this habitat to heavy metals accumulation from industrial effluents.

Detailed yield of each inorganic element in ash is showed in Table 5. The yield from incineration at $600{ }^{\circ} \mathrm{C}$ and analysis of individual inorganic element through atomic adsorption spectroscopy (AAS) and capillary electrophoresis (CE) was almost similar. From the results, the major elements of $\mathrm{Na}, \mathrm{K}$ and $\mathrm{Cl}$ almost comprise $55-80 \%$ of the total ash content. These elements can be present in plant cell wall probably in two forms, as various salts such as oxalates, carbonates, and sulfates; or as inorganic 
moieties bound to the cell wall components such as carboxyl group of pectic materials (Saka, 2001). Nevertheless, we found that inorganic elements in nipa palm were water-soluble and almost $96 \%$ of the elements could be removed by cold water extraction except for $\mathrm{Si}$ which partly remained in the residue (Phaiboonsilpa et al., 2011). This could be due to the structure of silica itself which cannot be removed under the conditions applied. Regardless, Si content in nipa palm is comparatively low to the total ash content.

\subsection{Whole utilization of nipa palm}

Our previous research showed that nipa frond could be subjected to hot-compressed water system which is the same system currently under development for fuels production from hardwoods and softwoods. Moreover, the chemical composition of all parts of nipa palm was very similar to that of oil palm, but in detail some differences were found to exist. Since extensive research and development have already been made on oil palm utilization (Husin et al., 2002); initial development and utilization of nipa palm can be done in a similar manner.

Comprehensively, $\mathrm{C}_{5}$ content is high in nipa palm and the easiest use of this hemicellulose is a conversion to consumable xylitol or raw material for furfural, furfuryl-alcohol and furan-based bioplastics (Buranov and Mazza, 2008). This is because 
conventional fermentation with Saccharomyces cerevisiae is not applicable for high $\mathrm{C}_{5}$ containing biomass. However, genetically modified microorganisms or new fermentation methods could be alternatively explored for fuel production (Gírio et al., 2010; Nakamura et al., 2011).

The presence of a significant amount of inorganic elements in nipa palm may be a problem since these elements are known for fireside fouling, slagging and corrosion. Furthermore, Si content with the presence of alkaline metal elements tends to produce sticky, mobile liquid phase which can block airways in furnace or boilers (McKendry, 2002). Chemical leaching of inorganic materials is used to substantially improve the combustion properties of biomass fuels (Dayton et al., 1999). In fact, the elements in nipa palm were found to be easily removed by cold water extraction and this characteristic makes it easier for removal of excessive inorganic elements and has a potential to be exploited further for fuels and chemicals. 


\section{Conclusions}

Compared to wood, total content of cellulose, hemicellulose and lignin is low due to high ash content with other minor components. The majority of hemicellulose was pentosan as found in hardwoods, while in lignin, small amounts of $P$ unit was found in addition to $S$ and $G$ units. Unlike hardwoods, this characteristic is more similar to other monocotyledonous plant such as rice and wheat. Even though individual chemical compositions of various parts of nipa palm were different, the overall trend of the compositions was essentially the same. Based on these detailed chemical characteristics of nipa palm, there is a vast scope for its potential as raw materials for fuels and chemicals with minor restrictions in its high ash content. Each part of the nipa palm has its own special characteristics and may be exploited for suitable applications based on its individual superiority. However, the fundamental properties of cellulose, hemicellulose and lignin will add value to the abundant and easily available parts of nipa palm and consequently increase its economical use. This will also indirectly help local development and increase the environmental attribute of nipa palm. Further specific studies, however, is necessary and should be conducted to enhance the end-products which could be valuable fuels or chemicals. 


\section{Acknowledgements}

We would like to thank Dr Naohiro Matsui and Dr Yasuyuki Okimori from The General Environmental Technos Co. Ltd, Osaka; along with Dr Hitoshi Miyasaka and Mr Takahito Kakihira from The Kansai Electric Power Co. Inc., Kyoto, for their generous contribution towards this research. We would also like to thank the Municipal Mayor and the people of Infanta, Philippines; especially Mr Ron Crisostomo for their warm hospitality and help in providing samples for our research. 


\section{References}

AOAC Official Method, 2001. Crude protein in animal feed, forage, grain, and oilseeds, block digestion using copper catalyst, steam distillation into boric acid. AOAC International, Gaithersburg, MD.

Buranov, A.U., Mazza, G., 2008. Lignin in straw herbaceous crops. Ind. Crop Prod. 28 237-259.

Carpita, N.C., Gibeaut, D.M., 1993. Structural models of primary cell walls in flowering plants: Consistency of molecular structure with the physical properties of the walls during growth. Plant J. 3, 1-30.

Chen, C.L., 1992. Nitrobenzene and cupric oxide oxidations, in: Lin, S.Y., Dence, C.W. (Eds), Methods in lignin chemistry, Springer, Berlin, pp 301-312.

Creighton, R.H.J., Hibbert, H., 1944. Studies on Lignin and Related Compounds. LXXVI. Alkaline Nitrobenzene Oxidation of Corn Stalks. Isolation of $p$-Hydroxybenzaldehyde. J. Am. Chem. Soc. 66, 37-38.

Dayton, D.C., Jenkins, B.M., Turn, S.Q., Bakker, R.R., Williams, R.B., Belle-Oudry, D., Hill L.M., 1999. Release of inorganic elements from leached biomass during thermal conversion. Energy Fuel 13, 860-870.

Ehara, K., Takada, D., Saka, S., 2005. GC-MS and IR spectroscopic analyses of the 
lignin-derived products from softwood and hardwood treated in supercritical water. J. Wood Sci. 51, 256-261.

FAO - Food and Agriculture Organization of the United Nations, 1998. Available from: <http://www.fao.org/docrep/X0451E/x0451e00.HTM>. Retrieved January 2009.

Girio, F.M., Fonseca, C., Carvalheiro, F., Duarte, L.C., Marques, S., Bogel-Łukasik, R., 2010. Hemicelluloses for fuel ethanol: A review. Bioresour. Technol. 101, 4775-4800.

Hamilton, L.S., Murphy, D.H., 1988. Use and management of nipa palm (Nypa fruticans, Arecaceae): a review. Econ. Bot. 42, 206-213.

Humphreys, F.R., Kelley, J., 1961. A method for the determination of starch in wood. Ana. Chim. Acta 24, 66-70.

Husin, M., Ramli, R., Mokhtar, A., Hassan, W.H.W, Hassan, K., Mamat, R., Aziz, A.A., 2002. Research and development of oil palm biomass utilization in wood-based industries. Malaysian Palm Oil Board. Available from:< http://palmoilis.mpob.gov.my/ publications/pod36_1-5.pdf>. Retrieved January 2011.

Jahan, M.S., Chowdhury, D.A.N, Islam, M.K., 2006. Characterization and evaluation of golpata fronds as pulping raw materials. Bioresour. Technol. 97, 401-406.

Jarvis, M.C., 1994. Solid-state NMR study of leaf cell walls of oil palm. Phytochem. 35, 
485-487.

Katahira, R., Nakatsubo, F., 2001. Determination of nitrobenzene oxidation products by GC and ${ }^{1} \mathrm{H}-\mathrm{NMR}$ spectroscopy using 5 -iodovanillin as a new internal standard. J. Wood Sci. $47,378-382$.

Kruse, K., Frühwald, A., 2001. Properties of nipa and coconut fibers and production and properties of particle and MDF-boards made from nipa and coconut, in: Bundesforschungsanstalt für Forst- und Holzwirtschaft Nr. 04, Hamburg.

Lapierre, C., 1993. Application of new methods for the investigations of lignin structure, in: Jung, H.G., Buxton, D.R., Hatfield, R.D., Ralph, J. (Eds), Forage Cell Wall Structure and Digestibility. American Society of Agronomy, Madison, pp. 133-166.

McKendry, P., 2002. Energy production from biomass: overview of biomass (Part 1). Bioresour. Technol. 83, 37-46.

Musha, Y., Goring, D.A.I., 1974. Klason and acid-soluble lignin content of hardwoods. Wood Sci. 7, 133-134.

Nakamura, Y., Miyafuji, H., Kawamoto, H., Saka, S., 2011. Acetic acid fermentability of standard compounds with Clostridium thermoaceticum and Clostridium thermocellum found in beech wood as produced in hot-compressed water. J. Wood Sci. doi: $10.1007 / \mathrm{s} 10086-010-1169-3$ 
Osabor, V.N., Egbung, G.E., Okafor, P.C., 2008. Chemical profile of Nypa fruticans from

Cross River Estuary, South Eastern Nigeria. Pakistan J. Nutr. 7, 146-150.

Phaiboonsilpa, N., Tamunaidu, P., Saka, S., 2011. Two-step hydrolysis of nipa (Nypa fruticans) frond as treated by semi-flow hot-compressed water. Holzforschung. In Press. Rabemanolontsoa, H., Ayada, S., Saka, S., 2010. Method applicable to analyze chemical composition of various biomass resources. Abstracts of the $60^{\text {th }}$ Annual Meeting of the Japan Wood Research Society, March 17-19, 2010, Miyazaki, Japan, pp. 90.

Rahman, L.M., 2000. The Sundarbans: A Unique Wilderness of the World, in: McCool, S.F., Cole, D.N., Borrie, W. T., O'Loughlin, J. (Eds), Wilderness science in a time of change conference- Volume 2: Wilderness within the context of larger systems; 1999 May 23-27; Missoula, MT. Proceedings RMRS-P-15-VOL-2. Ogden, U.S. Department of Agriculture, Forest Service, Rocky Mountain Research Station.

Robertson, A.I., Alongi, D.M., Boto, K.G., 1992. Food chains and carbon fluxes, in: Robertson, A.I., Alongi, D.M. (Eds), Tropical mangrove ecosystems, American Geophysical Union, Washington D.C, pp 293-326.

Saka, S., 2001. Chemical composition and distribution, in: Hon, D.N-S., Shiraishi, N. (Eds), Wood and cellulosic chemistry, Marcel Dekker, New York, pp 51-81. 
Shibata, M., Varman, M, Tono, Y., Miyafuji, H., Saka, S., 2008. Characterization in chemical composition of the oil palm (Elaeis guineensis). J. Jpn. I. Energy 87, 383-388.

Sun, R.C., Fang, J.M., Tomkinson, J., 1999. Fractional isolation and structural characterization of lignins from oil palm trunk and empty fruit bunch fibers. J. Wood Chem. Technol. 19, 335-356.

Sundberg, A., Sundberg, K., Lillandt, C., Holmbom, B., 1996. Determination of hemicelluloses and pectins in wood and pulp fibres by acid methanolysis and gas chromatography. Nord. Pulp Paper Res. J. 11, 216-219.

Suzuki, S., Rodriguez, E.B., Saito, K., Shintani, H., liyama, K., 1998. Compositional and structural characteristics of residual biomass from tropical plantations. J. Wood Sci. 44, 40-46.

Tono, Y., Miyafuji, H., Shibata, M., Saka, S., 2007. Characterization of the inorganic elements in oil palm (Elaeis guineensis). J. Jpn. I. Energy 86, 973-977.

Udofia, S.I, Udo, E.S., 2005. Local knowledge of the utilization of nipa palm (Nypa fruticans, Wurmb) in the coastal areas of Akwa lbom State, Nigeria. Glob. J. Agr. Sci. 4, 33-40.

Uhl, N. W. (1972). Inflorescence and Flower Structure in Nypa Fruticans (Palmae). Am. J. Bot. 59, 729-743. 
van Dam, J.E.G., van den Oever, M.J.A., Keijers, E.R.P, van der Putten, J.C., Anayron, C, Josol, F., Peralta, A., 2006. Process for production of high density / high performance binderless boards from whole coconut husk. Part 2: Coconut husk morphology, composition and properties. Ind. Crops Prod. 24, 96-104.

WAC- World Agroforestry Centre, 2008. Agroforestry Tree Database: Nypa fruticans. Available from: <http://www.worldagroforestrycentre.org/sea/products/AFDbases/AF/asp /spesiesinfo.as.> Retrieved May 2008.

Wankasi, D., Horsfall, M. J., Spiff, A. I., 2005. Desorption of $\mathrm{Pb}^{2+}$ and $\mathrm{Cu}^{2+}$ from Nipa palm (Nypa fruticans Wurmb) biomass. Afr. J. Biotechnol. 4, 923-927.

Yasuda, S., Fukushima, K., Kakehi A., 2001. Formation and chemical structures of acid-soluble lignin I: sulfuric acid treatment time and acid-soluble lignin content of hardwood. J. Wood Sci. 47, 69-72. 


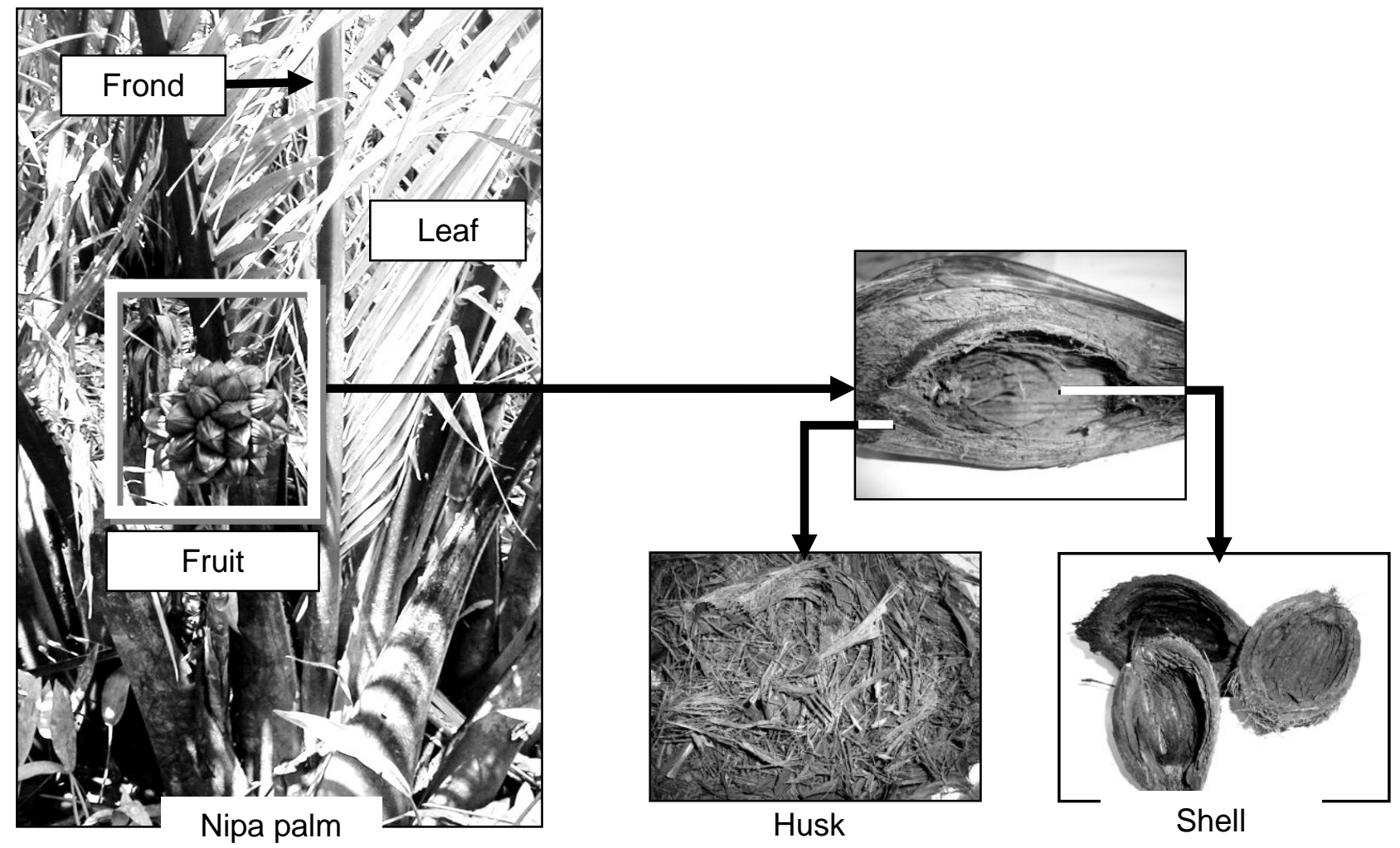

Fig. 1. Various parts of the nipa palm used in this study 
Table 1 Chemical composition of various parts of nipa palm (wt\% of the original oven-dried sample basis)

\begin{tabular}{|c|c|c|c|c|c|c|c|c|c|}
\hline \multirow[b]{2}{*}{ Parts } & \multirow[b]{2}{*}{ Cellulose $^{1}$} & \multirow[b]{2}{*}{ Hemicellulose ${ }^{2}$} & \multicolumn{2}{|c|}{ Lignin } & \multirow[b]{2}{*}{ Starch } & \multirow[b]{2}{*}{ Protein } & \multirow[b]{2}{*}{ Extractives $^{3}$} & \multirow[b]{2}{*}{ Ash } & \multirow[b]{2}{*}{ Total } \\
\hline & & & Klason & $\begin{array}{c}\text { Acid-solu } \\
\text { ble }\end{array}$ & & & & & \\
\hline Frond & 35.1 & 26.4 & 17.8 & 1.9 & 0.3 & 1.9 & 1.9 & 11.7 & 97.0 \\
\hline Shell & 45.6 & 23.5 & 17.3 & 2.1 & n.d & 0.8 & 1.3 & 8.2 & 98.8 \\
\hline Husk & 36.5 & 21.8 & 27.3 & 1.5 & 0.1 & 1.9 & 0.8 & 8.1 & 98.0 \\
\hline Leaf & 28.9 & 23.6 & 32.0 & 1.8 & 2.8 & 3.0 & 2.3 & 5.1 & 99.5 \\
\hline
\end{tabular}

${ }^{1}$ Cellulose $=\alpha-$ Cellulose $;{ }^{2}$ Hemicellulose $=$ Holocellulose $-(\alpha-C e l l u l o s e) ;{ }^{3}$ Extraction was done for $24 \mathrm{~h}$ using acetone $;$ n.d; not detected 
Table 2 Neutral sugars and uronic acid contents of various parts of nipa palm (wt\% of the original oven-dried sample basis)

\begin{tabular}{lccccccccc}
\hline \multirow{2}{*}{ Part } & Hemicellulose (1) & Hemicellulose (2) & \multicolumn{6}{c}{ Neutral sugars and uronic acid (wt\%) } \\
\cline { 4 - 9 } & & Glc & Gal & Man & Rhm & Xyl & Ara & UA \\
\hline Frond & 26.4 & 25.7 & 3.0 & 1.9 & 1.0 & 0.2 & 16.4 & 2.7 & 3.7 \\
Shell & 23.5 & 24.9 & 3.8 & 1.6 & 0.3 & 0.2 & 17.3 & 1.6 & 3.3 \\
Husk & 21.8 & 21.0 & 3.6 & 1.8 & 0.4 & 0.1 & 14.0 & 1.8 & 2.0 \\
Leaf & 23.6 & 23.4 & 2.9 & 2.4 & 0.4 & 0.2 & 17.0 & 1.8 & 1.5 \\
\hline
\end{tabular}

Glc: Glucose, Gal: Galactose, Man: Mannose, Rhm: Rhamnose, Xyl: Xylose, Ara: Arabinose, UA: Uronic acid

Hemicellulose $(1)=$ Holocellulose $-(\alpha-$ Cellulose $)$

Hemicellulose $(2)=162 / 180\left(\sum\right.$ Hexose $)+132 / 150\left(\sum\right.$ Pentose $)+176 / 194$ Uronic acid 
Table 3 Hexose $\left(C_{6}\right)$ and pentose $\left(C_{5}\right)$ contents of various parts of nipa palm (wt\% of the original oven-dried sample basis)

\begin{tabular}{lcccc}
\hline Part & Hemicellulose & Hexose $\left(\mathrm{C}_{6}\right)$ & Pentose $\left(\mathrm{C}_{5}\right)$ & Uronic Acid \\
\hline Frond & 25.7 & $6.1(21.1)$ & $19.1(66.1)$ & $3.7(12.8)$ \\
Shell & 24.9 & $5.9(21.0)$ & $18.9(67.3)$ & $3.3(11.7)$ \\
Husk & 21.0 & $5.9(24.9)$ & $15.8(66.7)$ & $2.0(8.4)$ \\
Leaf & 23.4 & $5.9(22.5)$ & $18.8(71.8)$ & $1.5(5.7)$ \\
\hline
\end{tabular}

The values in parentheses are wt\% ratio for the total hemicellulose 
Table 4 Molar ratio of syringyl propane and p-hydroxyphenylpropane moieties to guaiacyl propane moiety in alkaline nitrobenzene oxidation products of the various parts of nipa palm

\begin{tabular}{lcccc}
\hline Part & $\begin{array}{c}\text { Lignin } \\
(\text { wt\% })\end{array}$ & $\mathrm{G}$ & $\mathrm{S}$ & Lignin $(\mathrm{mol} / \mathrm{mol})$ \\
\hline Frond & 19.7 & 1.0 & 1.2 & 0.1 \\
Shell & 19.4 & 1.0 & 4.9 & 0.1 \\
Husk & 28.8 & 1.0 & 1.0 & 0.2 \\
Leaf & 33.8 & 1.0 & 2.8 & 0.2 \\
\hline
\end{tabular}

G: Guaiacyl propane unit, S: Syringyl propane unit, P: $p$-hydroxyphenylpropane unit 


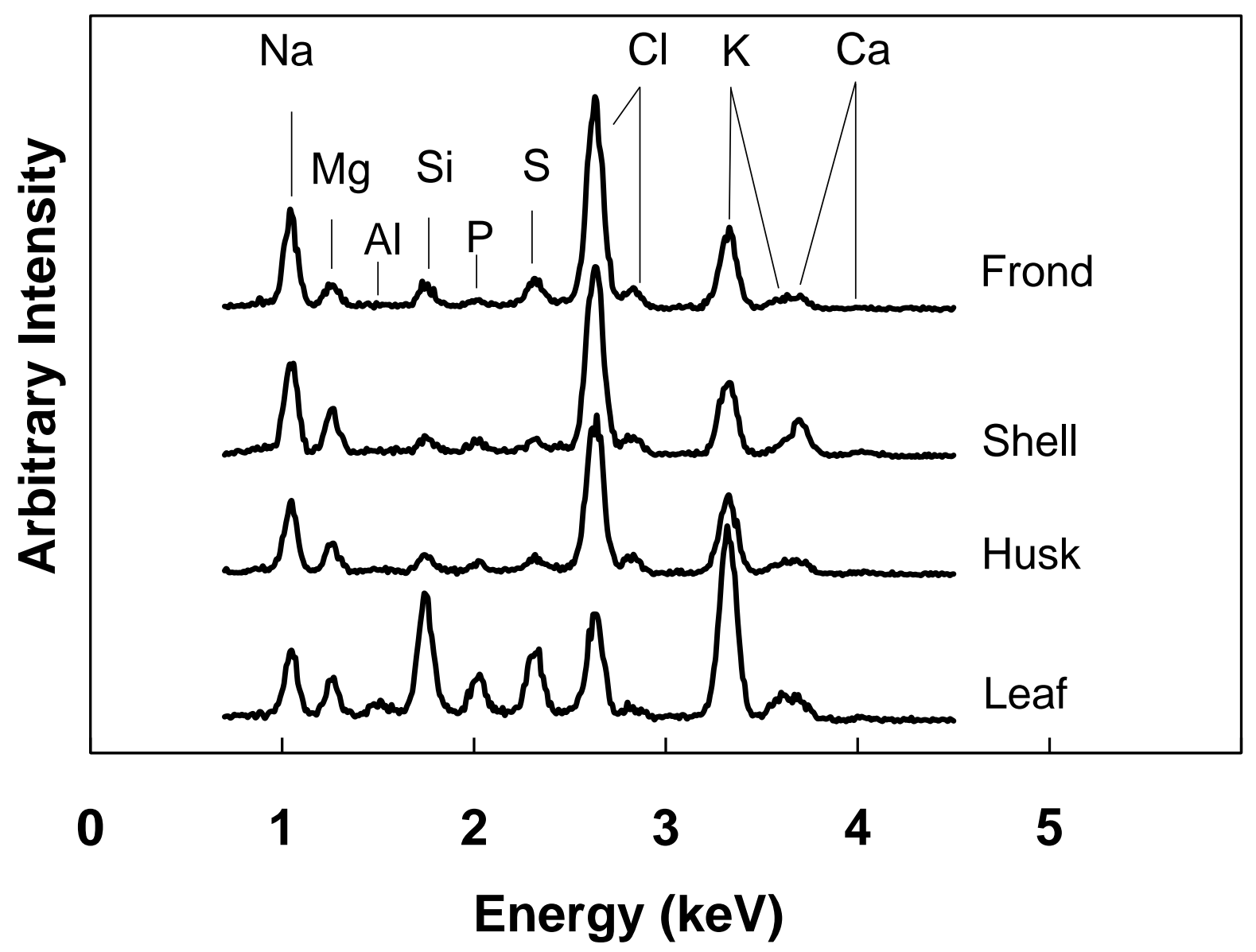

Fig. 2. EDX spectra of ashes obtained from various parts of nipa palm 
Table 5 Inorganic elements in ash obtained from various parts of nipa palm

\begin{tabular}{lcccccccccccc}
\hline & \multirow{2}{*}{$\begin{array}{c}\text { Ash } \\
\text { Part }\end{array}$} & Ash $^{2}$ & \multicolumn{8}{c}{ Inorganic elements (wt\%) } \\
\cline { 6 - 12 } & $(\mathrm{wt} \%)$ & $(\mathrm{wt} \%)$ & $\mathrm{Na}$ & $\mathrm{Mg}$ & $\mathrm{Al}$ & $\mathrm{Si}$ & $\mathrm{P}$ & $\mathrm{S}$ & $\mathrm{Cl}$ & $\mathrm{K}$ & $\mathrm{Ca}$ \\
\hline Frond & 11.7 & 11.4 & 2.0 & 0.5 & $\mathrm{n} . \mathrm{d}$ & 0.5 & 0.3 & 0.8 & 5.0 & 2.1 & 0.2 \\
Shell & 8.2 & 8.0 & 1.3 & 0.6 & 0.1 & 0.3 & 0.3 & 0.3 & 3.0 & 1.5 & 0.6 \\
Husk & 8.1 & 8.0 & 1.1 & 0.5 & 0.1 & 0.4 & 0.2 & 0.4 & 3.2 & 1.8 & 0.3 \\
Leaf & 5.1 & 4.9 & 0.4 & 0.3 & 0.1 & 0.8 & 0.3 & 0.5 & 0.7 & 1.6 & 0.2 \\
\hline
\end{tabular}

1 Obtained from incineration at $600^{\circ} \mathrm{C}$ for $2 \mathrm{~h} ;{ }^{2}$ Total yield from atomic absorption spectroscopy and capillary electrophoresis analysis; n.d: Not detected 